Received: 25/03/2019

Revision: 06/04/2020

Accepted: 27/04/2020

OnlineFirst: $18 / 07 / 2020$

\title{
Instructional Practices in Science Education in German and Malaysian Secondary Schools: A Comparative Case Study
}

\section{Salmiza Saleh}

Assoc. Prof., correspondence author, School of Educational Studies, Universiti Sains Malaysia, Malaysia, salmiza@usm.my

Tay Ai Jing

School of Educational Studies, Universiti Sains Malaysia, Malaysia, aijing1@hotmail.com

The purpose of this study is to compare the instructional practices in science education in Malaysian and German secondary schools. Specifically, the objectives of this research are to seek answers for the following questions: (i) What are the current science teachers' instructional practices in German secondary school? (ii) What are the current science teachers' instructional practices in Malaysian secondary school? (iii) What are the similarities and differences in the science teachers' instructional practices between Malaysian and German secondary schools? This case study involved a total of eight science teachers, four from the German secondary schools and four from the Malaysian secondary schools participated in this study. Classroom observation and semi-structure interview were conducted to obtain the data. Findings showed that the current instructional practices used by the German science teachers are more toward the alternative approach whereas Malaysian science teachers are lean towards the traditional approach. It is also found that there are similarities and differences in the science teachers' instructional practices in Malaysian and German secondary schools.

Keywords: comparative, instructional practices, science education, secondary school, Malaysia, Germany

\section{INTRODUCTION}

Students' science achievement, understanding of concepts, attitude and interest are widely published and studied across countries on science education (Eloranta \& YliPanula, 2005; Lindemann-Matthies et al., 2011; Prokop et al., 2009; Reiss et al., 2002; Sjøberg \& Schreider, 2010; Fidler \& Dillon, 2011). Although there are several studies investigated the instructional practices from the lens of TIMSS and PISA achievements 
across countries (Lau \& Lam, 2017; Mostafa, Echazarra \& Guillou, 2018), there have been limited research that compare the natures of teachers' instructional practices.

Instructional practices generally refer to the action taken by the teachers in developing the lesson in the classroom. It is the teachers' characteristics and behaviors that lead their classes and consistently used over time. Numerous researchers have utilized the word teaching approach or teaching style to described instructional practices. As per Dancy and Henderson's (2017) framework, there are two types of instructional practices which are the traditional instructional practices and alternative instructional practices.

Traditional instructional practices are also called as teacher-centered practices. Traditional instructional practices are a formal and controlled instructional practices where the instructor plan what, when and how students learn (Dupin-Bryant, 2004; Horvat-Samardžija, 2011). Traditional instructional practices are regularly connected with transmission models of teaching which includes drill and practice. Teacher acts as the primary source of information and evaluator whereas students receive the knowledge passively (Emaliana, 2017). Typical characteristics of traditional instructional practices are teacher who talks more, provides information, and rely much on textbooks (Emaliana, 2017). The main focus is getting the students to perform well on state mandated tests as opposed to taking into account on students' need (Zohrabi, et al., 2012) and there is limited space for student's personal growth.

Alternative instructional practices are simply referred as student-centered teaching approach. Alternative instructional practices can be defined as a style of instruction that is responsive, collaborative, problem-centered, and democratic in which both students and the teacher decide how, what, and when learning occurs (Dupin-Bryant, 2004; Dancy \& Henderson, 2007; Horvat-Samardžija, 2011). Alternative instructional practices centers around the learners' encounters, points of view, interests, capacities and needs. It creates a conducive learning environment for all learners, gives students responsibility for their learning and helps them make necessary decisions and value judgments about the relevance of the content to their own lives and interests (Brown, 2008). In alternative instructional practices, teacher plays the part of a facilitator or guide who helps students accomplish their goals (Wolk, 2010). Teachers who practice the alternative instruction do not just depend on textbooks, they encourage dynamic commitment and emphasize understanding of subject content instead of rote memorization of facts. Research showed that students performed better academically in alternative instructional practices because they able to contribute actively in their learning (Walsh \& Vandiver, 2007; Hassidov, 2019). This approach links with flexible learning, experiential learning, and self-directed learning (Acat \& Dönmez, 2009).

Numerous investigations had focused on the aspects of effective teaching practices which were related to students' accomplishment, performance and the learning process. Studies show that interactive teaching techniques are effective in teaching school children (Ko, Sammons \& Bakkum, 2014; Ko, Sammons \& Bakkum, 2013). They locate that interactive teaching is related with higher gains in test scores. In science education, instructional practices approaches such as (i) Engaging Resilient Preconceptions (addressing students' initial understanding and preconceptions about 
topics), (ii) Organizing Knowledge around Core Concepts (providing a foundation of factual knowledge and conceptual understanding), (iii) Supporting Metacognition and Student Self-Regulation (teaching strategies that will help students take control of their learning) and (iv) Cooperative Learning (allowing students to learn together) are proven among best instructional practices in schools (National Research Council, 2005).

However, in the case of Malaysia, a classical study found that although most science teachers had great knowledge, understanding and skills of the teaching contents and pedagogy, the frequent utilised instructional practices were still remain teacher-centered (Jemaah Nazir Sekolah Persekutuan, 1996). Indeed, some teachers prefer to proceed with the traditional practices as opposed to alternative approach (Saleh \& Aziz, 2012; Saleh \& Yakob, 2014). Besides, the instructional practices in the classroom frequently happened by method for showing materials from a textbook. Teachers conducted demonstrations and laboratory activities occasionally to verifying the concepts taught in classroom and explaining some exercises given at the end of the textbook, in order familiarize students with examination questions (Saleh \& Aziz, 2012; Effandi \& Zanaton, 2007; Saleh \& Aziz, 2012; Saleh \& Yakob, 2014; Tan \& Arshad, 2011, OECD, 2009). Research also show that the instructional practices in Malaysia has a negligible level of interaction, whereby the teachers complete a substantial part of the talking and instructing while only several students contributed their views (Saleh \& Aziz, 2012; Saleh \& Yakob, 2014). As a results, it can be seen that Malaysian students are still left behind in many aspects compared to their colleagues especially from advanced countries such as Germany.

In Germany, one of the factors contributing to students' outcomes and success is the teacher's instructional practices. However, studies show that there are no single mode of teaching characterizes German instructional practice. Most teachers in Germany embrace a various style of teaching that incorporates several methodologies in each lesson. Group work and peer tutoring are used more frequently by teachers in Grundschule and Hauptschule than by those in Realschule (Stevenson \& Nerison-Low, n.d.). Moreover, Hauptschule teachers made themselves reachable after class and frequently organized group work and peer tutoring to reduce academic problems among the students (Stevenson \& Nerison-Low, n.d.). German teachers believe that it is their duty to convey the weaker students along and to assist them. On the other hand, Gymnasium teachers focus on academic instruction though a lecture format, class discussions and students' presentations and their classes are in fast paced (Stevenson \& Nerison-Low, n.d.).

Thus, the purpose of this research is to seek answers for the following questions:

- What are the current science teachers' instructional practices in German secondary school?

- What are the current science teachers' instructional practices in Malaysian secondary school? 
- What are the similarities and differences in the science teachers' instructional practices between Malaysian and German secondary schools?

\section{Framework for Articulating Instructional Practices}

To answer the research questions stated above, Dancy and Henderson's (2007) comprehensive framework as explained in the table below was drawn up and used in this study.

Table 1

Main Categories of Practices

\begin{tabular}{|c|c|c|}
\hline & $\begin{array}{l}\text { Practices consistent with traditional } \\
\text { instruction }\end{array}$ & $\begin{array}{l}\text { Practices consistent with alternative } \\
\text { instruction }\end{array}$ \\
\hline Interactivity & One-sided discourse, passive students & Conversations, active students \\
\hline $\begin{array}{l}\text { Instructional } \\
\text { decisions }\end{array}$ & Decision made by teacher & $\begin{array}{l}\text { Decision shared by teacher and } \\
\text { students }\end{array}$ \\
\hline $\begin{array}{l}\text { Knowledge } \\
\text { source }\end{array}$ & Students receive expert knowledge & Students develop own knowledge \\
\hline $\begin{array}{l}\text { Student } \\
\text { success }\end{array}$ & Success against pre-set standards & $\begin{array}{l}\text { Success measured by individual } \\
\text { improvement }\end{array}$ \\
\hline $\begin{array}{l}\text { Learning } \\
\text { mode }\end{array}$ & $\begin{array}{l}\text { Competitive or individualistic } \\
\text { learning mode }\end{array}$ & Cooperative learning modes \\
\hline Motivation & External motivators & Internal motivators \\
\hline Assessment & Knowledge-based assessment & Process based assessment \\
\hline Content & $\begin{array}{l}\text { Explicitly teach only science facts and } \\
\text { principles }\end{array}$ & $\begin{array}{l}\text { Explicitly teach learning, thinking } \\
\text { and problem-solving skills in addition } \\
\text { to science content }\end{array}$ \\
\hline $\begin{array}{l}\text { Instructional } \\
\text { design }\end{array}$ & $\begin{array}{l}\text { Knowledge driven based on } \\
\text { understanding of the structure of } \\
\text { science }\end{array}$ & $\begin{array}{l}\text { Student driven based on } \\
\text { understanding of student learning } \\
\text { within the discipline of science }\end{array}$ \\
\hline $\begin{array}{l}\text { Problem } \\
\text { solving }\end{array}$ & $\begin{array}{l}\text { Formulae problem solving: Problems } \\
\text { assigned to students are well defined } \\
\text { and similar to the problems students } \\
\text { have previously seen }\end{array}$ & $\begin{array}{l}\text { Creative problem solving: Problems } \\
\text { assigned to students are novel to } \\
\text { solve and may have unknown or } \\
\text { open-ended solutions }\end{array}$ \\
\hline
\end{tabular}

\section{METHOD}

In order to extract data to address the research questions, a comparative case study method was used. This research methodology allowed the researcher to understand and compare the instructional practices of two nations. The sample drawn via purposive sampling technique, included four teachers who were teaching the science subject in Year 10 in four German secondary schools and four Malaysian science teachers who were teaching the same science subject of Form 4 classes (similar to Year 10) in four Malaysian secondary schools. The samples of teachers involved in this study were those who willing and agreed to take part in this research. The main data collection involved the classroom observations and holding semi-structured individual interviews with the teachers in their schools.

In the classroom observation, overt and unstructured observation approaches had been used. The researcher participated in the lesson by sitting at the end of the classroom and 
observed the lesson conducted. The participants were acknowledged before the researcher observed the lesson. The researcher observed the classrooms of the same participant at least two times during their regular classroom work to ensure the consistencies of the data collected. The researcher then jotted down everything that could be seen throughout the classroom observation. Each teacher was observed for at least three times in three months during his/her lesson time. Altogether there were 12 lessons observed from 4 teachers in Germany and 12 lessons observed from four teachers in Malaysia.

Moreover, a semi-structured interview was conducted with the sample to investigate qualitatively and research further into issues that were impractical to obtain from classroom observation (Fraenkel, Wallen, \& Hyun, 2012). This method provided the opportunity for the researcher to re-interview with the same participants that involved in the classroom observation. The questions asked in the semi-structured interview were related to the research questions where the theme cannot be observed from the classroom observation

Data gathered were then analysed qualitatively within and across each source using Braun and Clarke's (2006) thematic analysis structure approach. Once the data set had been read, re-read, coded and re-coded, all of the codes created were collated into possible themes and then listed in categories according to Dancy and Henderson's (2007) framework.

\section{FINDINGS AND DISCUSSION}

To further discuss the results, it is important to highlight here that Teacher A, B, C and D are the German science teachers whereas Teacher E, F, G and H are the Malaysian Science teachers.

\section{Current Science Teachers' Instructional Practices in German Secondary School}

Data from classroom observations showed that in German secondary schools, the instructional practices were more towards a two-way communication approach. Teachers always asked open questions in the lesson. Teacher A and Teacher B started the lesson by just giving the title of the topic and followed by asking questions related to it. The students were then actively responded to the questions asked by their teacher. Moreover, Teacher B involved the students in the demonstration. However, there were some lessons conducted in the traditional way where the teacher did most of the talking and the students jotted down the note. Teacher $\mathrm{C}$ asked the students to refer to the textbook during his lesson. He summarised the definition in the textbook and asked the students to jot down the notes. Both of the teachers, Teacher B and Teacher C demonstrated the science concept in front of the classroom instead of requiring the students to visualize particular concept. Nonetheless, Teacher $\mathrm{C}$ tried to involve the students during the demonstration of thermal equilibrium experiment by asking the students to check on the time while he read the reading of the temperature on the thermometer. As Björkman and Tiemanna (2013) found, this finding confirmed that class discussion is a very ruling teaching method in the German lessons. The lesson 
conducted by moving from individual conceptions to a shared scientific understanding of the problem (Tytler, Chen \& Freitag-Amtmann, 2017).

Stevenson and Nerison-Low (n.d.) state that German teachers encouraged peer tutoring in Hauptschule but not in Gymnasium. Based on this study, it was found that most teachers adopted a diverse style of teaching that incorporated several strategies in each lesson (Stevenson \& Nerison-Low, n.d.). Therefore, the instructional decision was shared by the teacher and the students. The students had a chance to share their experiences with their peers in the classroom. Teacher A picked a student to choose an example of alkane before he taught combustion of alkane. He used the example given by the student to show the equation of the combustion. Teacher B asked the students to think of the results after a demonstration was done in the lesson. He allowed the students to share their ideas in the classroom before he further explained on the concept. Besides, Teacher $\mathrm{C}$ asked the students to do some simple experiments at home and shared them with their classmates. Teacher D also did the same with his students. He asked the students to search information related to virus from the internet at home, created a mind map using their devices and presented it in the classroom.

In terms of knowledge source, it was found that two of the German science teachers allowed their students to develop their own knowledge in the lesson where another two transferred the science knowledge to their students. In overall, the students were given chance to design their own experiments. For example, in Teacher B's lesson, the students had to work in pair to conduct an experiment related to induction. Teacher D on the other hand, guided students to do the experiment and discussed the related science concepts with them. All the four teachers posed problems actively to stimulate classroom discussion. It could be seen that students in each class that had been observed were also actively posed questions in the lessons conducted by all the four German science teachers.

Findings from semi-structured interview showed that all the teachers measured the success of the students by individual improvement. Teacher A said that a successful student is a student who has learnt to improvise and adapt with the knowledge he gets and uses that knowledge in his life. Teacher B had a view that a successful student is someone who interested in the subject learnt whereas Teacher $\mathrm{C}$ thought that a successful student is someone who likes what he is doing, and could bring with him the value of the lesson in his life. Whereas teacher D measured his students' success based on the following criteria which are highly motivated, responsible, able to think critically, always ask questions and most importantly can be a team-player to collaborate with the rest of students. On the other hand, all the teachers agreed that they have to be good enough to pass the examinations.

When it comes to the learning mode, the German science teachers' lesson stayed in between the traditional and alternative teaching methods. All four German science teachers encouraged group work. They used small groups and peer tutoring as integral parts of classroom instruction which enabled them to understand their students well and give proper sorts of help (Stevenson \& Nerison-Low, n.d.). However, the students were 
still graded individually. The mark of the assignment was given based on the individual work and not group work.

Other than that, the German science teachers played a role as the internal motivator. All the four science teachers always ask feedback from the students throughout the lesson. They also always praise their students when they answer the questions correctly. They would also correct their students patiently when the students made mistakes. This approach helps students to learn effectively as they are given the opportunities to reflect on their learning (Msimanga, 2017). All the four teachers were also connected the topic to their students' interest to increase students' motivation to learn science.

The assessment methods used by the German science teachers were more towards traditional instructional practices. Interview findings revealed that the questions asked in the final examinations were the familiar problems taught by the teacher in the classroom. Teachers disclosed that most of the questions were tested for factual recall and only $20 \%$ of the questions were based on the students' understanding. Teacher B said examination is always a mixture between the majority questions of reproduction or simple questions and maybe one-third of more difficult questions where the students have to think in the other direction. According to Teacher B, $60 \%$ to $70 \%$ of the questions would be reproduction where the rest would be on transfer questions. Transfer questions are the questions where the students have to use their knowledge for new problems. It went the same as for Teacher $\mathrm{C}$. Teacher $\mathrm{C}$ stated that mostly, the questions in the examinations are similar, but it depended on the ability of the students to cope with the questions. Teacher $\mathrm{C}$ also added that there are more transfer questions in the examination for a better academic class. As Teacher C and Teacher B, Teacher A and Teacher D also focused on the past year questions to assess their students. According to Stevenson and Nerison-Low (n.d.), Gymnasium classes are in fast paced and seek to derive the right answer. Thus, most of the German teachers asked familiar questions in their assessment.

Moreover, three out of four German science teachers were found to use knowledgebased content in their lesson. These were opposed to Tytler, Chen and Freitag-Amtmann (2017) opinion, whom stated that German students explore, record and share findings in the lesson. Findings from this study showed that most of the German science teachers tended to teach physical facts and principles only in their lesson. However, Teacher C was found to encourage higher order thinking skills' activities where students had to find on their own the science formula to solve the problems or questions related to the lesson (thermal equilibrium).

In terms of problems solving, the results showed that the German science teachers' teaching approach stayed in between the traditional and alternative instructional practices. It was observed that the German science teachers expected the students to explain and predict the answer posed by them. In both lessons, the solutions were expected to include a correct numerical answer. However, most of the problems were well-defined problems which only problem with necessary information would be used. 


\section{Current Science Teachers' Instructional Practices in Malaysia Secondary School}

Findings showed that most of the instructional practices in the Malaysian schools were still dominated by teachers who were more inclined to practice one-way communication. The teachers directly delivered the information to the students. It had minimal levels of interaction, whereby it was the teachers who did much of the talking and teaching, while the students just copied the notes. Only a few of the students got to speak up and contributed their views. In most of the theoretical classes, teachers tended to explain scientific facts and concepts, words and contents along the way just like lecturing the class. However, the students were active when they were conducting the experiment. They discussed among themselves throughout the experiment where the teachers just gave a clear instruction before they started the experiment. The activities conducted in the classroom were the most on whole class lectures and followed by whole class discussions. These results are consistent with the previous findings by Saleh and Aziz (2012) and Saleh and Yakob (2014).

However, it is found that the instructional decision in Malaysian schools was not fully decided by the teachers. There were still sometimes where the teachers shared the instructional decision with their students. Though teachers were always the one who decided on what and when the lesson should be conducted in the classroom, the students still had the chances to share their views. However, the students only had a limited chance to answer the questions asked by the teachers. The results were contradicting to the previous findings which found that teachers were the ones who decided on classroom instructional decision (Saleh \&Yakob, 2014). It is proved from this study that the instructional decision in Malaysian schools were not fully decided by the teachers

Moreover, it was observed that all four teachers prepared the teaching and learning materials such as notes and experiment. The teachers distributed the materials to the students before the lesson started. It was seen that the students conducted the experiment based on the notes given to them and recorded the data collected from the experiment to write a report. In the theory class, the teachers tended to explain the lesson (Sim \& Ashrad, 2013) and transmitted all of the science knowledge by lecturing the students which sometimes led to spoon feeding (Tengku Kassim, 2014).

From the semi-structured interview session, it can be seen that all the four Malaysian science teachers measured the success of the students by individual improvement where this is consistent with the findings of Saleh and Yakob (2014). Teacher E said that a successful student does not only score well in the exam but has a good learning attitude. They need to have interest and willing to listen and always ask questions. It went the same as with Teacher $\mathrm{G}$ and Teacher $\mathrm{H}$ who also agreed that the right attitude is important for students' success. Teacher $\mathrm{F}$ always tell her students that all of them can score well in the examination if they are willing to try hard. For Teacher F, students who are working hard are considered as successful students although they might end out scoring an average result.

Moreover, the results showed that the Malaysian science teachers focused on individualistic learning mode in the theory lesson, and cooperative learning mode in 
facilitating experiments and drilling activities. All of the teachers in the observed lessons graded the students individually. The mark of the assignment was based on the individual work and not group work. Although the students conducted the experiment in pairs or groups, every student is required to submit a copy of report individually. The teachers would grade them based on the report handed in. These findings concur with the previous studies that reported teachers are still resort to the traditional styles in different teaching settings (Dupin-Bryan, 2004).

Furthermore, it was found that the Malaysian teachers were internal motivator where they gave comments and feedbacks to the students. It could be seen in the lesson conducted by two science teachers, Teacher E and Teacher F. Teacher F walked around the laboratory and told the students to add a wind shield when the cashew nut was burn strongly in one of the group during the experiment whereas Teacher E told the whole class on the mistakes they had done at the end of the experiment so that they did not repeat them again. This approach encouraged students to learn better as they had the opportunities to reflect on their learning (Msimanga, 2017).

Two out of four science teachers in Malaysian secondary school stated that the questions asked in the final examinations were the familiar problems taught in the classroom while another two of them focused on process-based assessment. Teacher $\mathrm{G}$ and Teacher $\mathrm{H}$ stated through the semi-structured interview session that most of the questions were tested for factual recall and only $20 \%$ of the examination questions were the application questions. They focused on the past year questions. However, Teacher E said that since currently Malaysian education system focuses on higher thinking order skill, so the questions must be changed consistent with this aim. Teacher E added that the questions asked in the final examination were no longer straight forward, so the students need to think. As per Teacher F, a more challenging question will help the students to understand well in the topic. Nonetheless, according to Teacher F, the repetition was only used in the questions which have a format for the students to remember.

Other than that, the Malaysian science teachers were found explicitly taught only facts and principles. They focused on derivations and formulas. For example, Teacher $\mathrm{H}$ emphasized the important of the calculation and unit in the exercise questions. Teacher $\mathrm{G}$ emphasized the way answering the questions by following the marking scheme. The students were resorted to memorizing facts to excel in their examinations and tests (Tengku Kasim, 2014).

Results also showed that Malaysian teachers' instructional design were based on understanding of the structure of science. They used knowledge-driven instructional design in their lesson. The lesson progression was basically fixed in advance. All of the Malaysian science teachers had a lesson plan on what, when and how the lesson conducted. Teachers tended to use their autonomy to decide and without giving the allowance of neither space nor opportunity for students to voice out (Saleh \& Aziz, 2012). Nonetheless, Teacher $H$ asked her students to present their idea about the Green building project that they had done to their classmates. 
Lastly, it was also found that most of the Malaysian science teachers were starting to use creative problems solving approach in their lessons. This showed some improvements compared to the previous findings where teachers used formula problem solving rather than creative problem solving (Saleh \& Aziz, 2012; Saleh \& Yakob, 2014). It was also observed that the Malaysian science teachers expected their students to explain and predict the answer posed by them. The solutions were also expected to include a correct numerical answer. However, only well-defined problems with information necessary for the solution were used.

\section{Similarities and Differences of Science Teachers' Instructional Practices in Malaysia and German Secondary School}

Based on Dancy and Henderson's (2007) comprehensive framework, there are five out of ten categories of German science teachers' practices indicated alternative instructional practices, two out of ten categories which demonstrated the traditional practices and three out of ten categories of practices remain in between the alternative instructional practices and traditional instructional practices. On the other hand, two categories of the Malaysian science teachers' practices exhibited alternative instructional practices, five out of ten categories of practices are still traditional instructional practices and three categories of practices stay in between the alternative instructional practices and traditional instructional practices.

In the German secondary science lessons, it can be observed that the students actively discussed about the topic of the lesson with their teachers. In most of the lessons (eight out of 12 lessons observed), teachers made open inquiries in the lesson and asked the students to share their thoughts in the classroom. Active discussions took place in most of the learning activities. Be that as it may, there is a few lessons directed in the traditional way (four out of 12 lessons observed) where the teacher did most of the talking and the students scribble down the note. They utilised entire class frontinstructing that is to teach the class as a whole. They demonstrated the science concept in the classroom rather required the students to visualize particular concept. They trusted that learning process can be made easier and interesting by carried out demonstration. Demonstration using visible aids allowed the students to observe the concepts and processes directly. Although the teacher did most of the talking in explaining the concepts, the teachers tried their best to involve the students actively in the lesson. The students actively involved themselves by posing questions which this situation cannot be found in Malaysian secondary science classroom. This finding supported claim made by Tytler, Chen and Freitag-Amtmann (2017) that German science lessons were conducted through dialogue. In contrast, science lessons in Malaysian upper secondary school were mostly lecture style and the students were passive in the science lessons. They stayed quiet and tune in on what the teacher instructed in the classroom without involving themselves in exchanging their ideas. The lesson was mostly dominated by the teachers where the teachers directly deliver the information to the student. However, the students were active when they were conducting the experiment. 
Furthermore, the instructional decision in German secondary school was shared by the teacher and the students though the instructional decision. In Malaysian secondary school, it was mostly decided by the teachers. The students in Germany had the chance to share their experiences with their peers in the classroom. The German students shared the results of some simple experiments which were done at home to their classmate. The German science teachers additionally gave them chance in presenting the new knowledge and explaining it to their classmate. Nonetheless, the instructional decision in Malaysian schools was contrast with it. The Malaysian science teachers were the only individuals qualified to make any choices about the teaching practices applied in the classroom. The Malaysian science teachers choose the activities led in the lesson where the students have minimal opportunity to share their views where the students are only supposed to follow orders (Saleh \& Aziz, 2012; Saleh \& Yakob, 2014).

It can be seen from the classroom observations that the German students were given chances to built their own insight in the lesson. On the other hand, Malaysian students received expert knowledge. The German students outlined their own particular investigation and their teachers directed them while they planned and conducted the experiment. This was not found in Malaysian science classrooms. The Malaysian science teachers design the lesson fully and a large portion of them set up the teaching and learning materials, for example, notes and experiment before the lesson where the students would simply kick back and copy the notes in the lesson.

In view of the outcomes acquired, it can be seen that the two nations have the same perspective when defining the students' success. The students who achieved success are the individual who enjoy learning in the classroom, learnt different skills which will be useful for them in their future and most importantly have a good attitude in learning science. They must work hard for their examination.

From the data collected, it demonstrated that the German science teachers' instructional practices took after a pattern of discovery learning. The German teachers attempted to involve the entire class in the discussion. They taught the students to learn and think. The teacher guided the students to discover the concepts, theories or general equations without directly giving to them. This cannot be found in Malaysian science lesson where most of the teachers in Malaysia utilised lecture style in their lesson. They mostly spoon feeding the students by disclosing to them the appropriate response without giving the students opportunity to think as the education system in Malaysian are exam oriented (Tengku Kassim, 2014).

Besides, the German and Malaysian science teachers are the internal motivator. They always praise their students when students answer the questions correctly and correct them patiently when the students commit errors. They give feedbacks and comments to their students to avoid their students repeat on the same mistakes.

Despite the fact that the German science teachers encourage group work, the students are as yet evaluated individually just like in Malaysia. Both countries have the final examination at the end of the secondary school. It is a must for the students to sit for the final examination before they complete their secondary school and obtain a certificate. 
The questions asked in the final examination were the familiar problems taught by the teacher in the classroom. The vast majority of the questions were tested for factual recall and only $20 \%$ of the questions were based on the students' understanding.

Other than that, Malaysian and German science teachers explicitly teach only science facts and principles. They centre around derivations and formulas as opposed to concentrating on the conceptual understandings. It supported Forbes et al. (2014) findings where German classrooms were afforded more generous chances to formulate prove based clarifications whereas the findings supported previous research where the Malaysian science teachers heavily depends on the textbook and having demonstrations or experiments that aimed to verify the science concepts taught (Saleh \& Aziz, 2012; Saleh \& Yakob, 2014)

In addition, the lesson conducted in German secondary school are based on students understanding. The lesson progression is adjustable and shaped by students inquires and remarks. Malaysian science teachers are as yet utilising the traditional instructional outline where the Malaysian science teachers are the one that fix the lesson progression. Malaysian science teachers' instructional design depended on comprehension of the structure of science. The lesson progression is fundamentally settled ahead of time. The Malaysian science teachers prepare a lesson plan before entering the class.

However, Malaysian and German science teachers have a similar view in problem solving. The Malaysian and German science teachers remain in between the traditional and alternative instructional practices in solving the problem. It was observed that the Malaysian and German science teachers anticipated the students would clarify and foresee the questions posed to them. The solutions are also expected to include a correct numerical answer. Notwithstanding, the problems posture in the German school incorporate some ill-defined which have excess information for the students to think before answer the questions whereas all the problems pose in Malaysian school are welldefined problems which only problem information necessary for the solution.

In light of the outcomes acquired from the classroom observations and semi-structure interviews, the current instructional practices used in German science lessons at the secondary school are more towards the alternative practices where the teacher facilitates the students in the science lesson whereas the current instructional practices in Malaysian secondary school are still the traditional method which is teacher-centred where most of the lessons are taught by the teacher without the involvement of the students. Thus, the results obtained showed the same findings as the past research where Malaysian instructional practices still dominated by the teachers and German science teachers used various style of teaching strategies.

\section{CONCLUSION}

In conclusion, this research found that in general, most of the Malaysian science teachers instructional design stayed in between the traditional and alternative practices. The lesson progression was still shaped by the teachers where they decided what to be achieved by their students. Whereas, most of the German science teachers' instructional 
design were more towards the alternative practices. The lesson progression was adjustable and shaped by the students' questions and comments.

There are similarities and differences in the science teachers' instructional practices in Malaysia and Germany. Both nations have the same method of assessments, similar perspectives in problem solving and the same views on the definition of successful students whereas the interactivity between the teacher and students, the instructional decisions made in the lesson, the knowledge source, the learning mode, motivation given by the teachers, the content used in the lesson and the instructional design showed huge different. The differences are not only found in both nations, it is also discovered on the science teachers from the same nation. Although the teachers implemented the same pedagogy in teaching, but the instructional practices used by the individual teachers may be different. Thus, it is impossible to determine the most effective teaching practices. It is highly impracticable that any teacher applies student-centered or teachercentered instruction in a classroom in its purest form although these two teaching approaches seem opposite to each other. However, it can be concluded that the science teachers' instructional practices in German secondary school are more towards the alternative instructional practices whereas the science teachers' instructional practices in Malaysia secondary school are still in the traditional instructional practices.

\section{Acknowledgement}

\section{USM RUI Grant No. 8016006}

\section{REFERENCES}

Acat, B., \& Dönmez, İ. (2009). To compare student centered education and teacher centered education in primary science and technology lesson in terms of learning environments. Procedia Social and Behavioral Sciences, 1, 1805-1809.

Björkmana, J., \& Tiemanna, R. (2013). Teaching patterns of scientific inquiry: A video study of chemistry lessons in Germany and Sweden. Science Education Review Letters Research Letters, 1-7.

Braun, V., \& Clarke, V. (2006). Using thematic analysis in psychology. Qualitative Research in Psychology, 3, 77-101. https://doi.org/10.1191/1478088706qp063oa.

Brown, J. K. (2008). Student-centered instruction: Involving students in their own education. Music Educators Journal, 94(5), 30-35.

Dancy, M., \& Henderson, C. (2007). Framework of articulating instructional practices and conceptions. Physical, Review Physics Education Research, 3(1), 010103. https://doi.org/10.1103/PhysRevSTPER.3.010103.

Dupin-Bryant, P. A. (2004). Teaching styles of interactive television instructors: A descriptive study. The American Journal of Distance Education, 18(1), 39-50. 
Effandi, Z., \& Zanaton, I. (2007). Promoting cooperative learning in science and mathematics education: A Malaysian perspective. Eurasia Journal of Mathematics, Science \& Technology Education, 3(1), 35-39.

Eloranta, V., \& Yli-Panula, E. (2005). Animals in the landscape drawings of Finnish and Russian young people: In the landscape they want to conserve. NorDiNa, 2, 5-17.

Emanalia, I, (2017). Teacher-centered or student-centered learning approach to promote learning? J Sos Human, 10(2), 59-70. https://doi.org/10.12962/j24433527.v10i2.2161.

Fidler P., \& Dillion, J. (2011). IRSE - interest and recruitment in science education. London: Kings College London. Retrieved from http://sciencecentres.org.uk/pdfs/IRIS.

Fraenkel, J. R., Wallen, N. E., \& Hyun, H. H. (2012). How to design and evaluate research in education. New York: McGraw-Hill.

Forbes, C., Lange, K., Möller, K., Biggers, M., Laux, M., \& Zangori, L. (2014). Explanation-construction in fourth-grade classrooms in Germany and the USA: A crossnational comparative video study. Int Journal of Science Education, 36(14), 2367-2390.

Hassidov, D. (2019). How teaching method (alternative/frontal) affects achievement in mathematics for boys and girls in grades four to six who are learning in a computerassisted environment. Creative Education, 10, 1425-1443

Horvat-Samardžija, D. (2011). Alternative and /or traditional way of teaching and evaluation in the 4th grade of nine-year primary school. Metodik obzori, 11(6), 161-164.

Jemaah Nazir Sekolah Persekutuan. (1996). Perlaksanaan program KBSM dalam bilik darjah. Kertas kerja Seminar Kebangsaan Penilaian KBSM. Institut Aminuddin Baki.

Ko, J., Sammons, P., \& Bakkum, L. (2014). Effective teaching. UK: Education Development Trust.

Ko, J., Sammons, P., \& Bakkum, L. (20013). Effective teaching: A review of research evidence. UK: CfBT Education Trust.

Lau, K. C., \& Lam, T.Y. (2017). Instructional practices and science performance of 10 top-performing regions in PISA 2015. Int J of Science Education, 39(15), 2128-2149.

Lindemann-Matthies, P., Constantinou, C., Lehnert, J. Nagel, U., Raper, G., \& KadjiBeltran, C. (2011). Confidence and perceived competence of preservice teachers to implement biodiversity education in primary schools- four comparative case studies from Europe. International Journal of Science Education, 33(16), 2247-2273.

Msimanga, M. R. (2017). Teach and assess: A strategy for effective teaching and learning in economic and management sciences (Unpublished doctoral dissertation). University of The Free State, Bloemfontein, South Africa. 
Mostafa, T., Echazarra, A., \& Guillou, H. (2018). The science of teaching science: An exploration of science teaching practices in PISA 2015. OECD Working Paper.

National Research Council. (2005). How students learn: History, mathematics, and science in the classroom. Washington D.C.: National Academies Press.

OECD. (2009). Creating effective teaching and learning environments: First results from TALIS. Paris: OECD Publishing.

Prokop, P., Uask, M., Özel, M., \& Fancovicová, J. (2009). Children's conceptions of animal breathing: A cross-age and cross cultural comparison. Journal of Baltic Science Education, 8(3), 191-208.

Reiss, M. J., Tunnicliffe, S. D., Moller-Anderson, A., Bartoszeck, A., Carvalho, G. S., Chen, S., Jarman, R., Jonsson, S., Manokore, V., Marchenko, N., Mulemwa, J., Novikova, T., Otuuka, J., Teppa, S., \& Rooy, W. V. (2002). An international study of young peoples' drawings of what is inside themselves. $J$ of Biological Edu. 36(2), 58-63.

Sjøberg, S., \& Schreiner, C. (2010). The ROSE project. An overview and key findings. Retrieved from http://eacea.ec.europa.eu/education/eurydice/ comparative study on Science and Mathematics education.

Saleh, S., \& Yakob, N. (2014). Teachers' conceptions about physics instruction: A case study in Malaysian Schools. Australian J of Basic and Applied Sci, 8(24), 340-347.

Saleh, S., \& Aziz, A., (2012). Teaching practices among secondary school teachers in Malaysia. Paper presented at 2nd International Conference on Education, Research and Innovation - ICERI 2012. Conference. Phnom Penh, Cambodia.

Stevenson, H. W., \& Nerison-Low R. (n.d.). To sum it up: Case studies of education in Germany, Japan, and the United States. U.S.: National Institute on Student Achievement, Curriculum, and Assessment Office of Educational Research and Improvement U.S. Department of Education.

Tan, Y. P., \& Arshad, M. Y. (2011). Problem-based learning: Implementation issues in Malaysia secondary schools' science classroom. Paper presented at the International Conference on Science \& Mathematics Education (CoSMEd) 2011, SEAMEO RECSAM. Penang, Malaysia.

Tengku Kasim, T. S. A. (2014). Teaching paradigms: An analysis of traditional and student-centred approaches. Journal of Usuluddin, 40, 199-218.

Tytler, R., Chen, H. S., \& Freitag-Amtmann, I. (2017). Inquiry teaching and learning within and across cultures. Paper presented at ESERA 2017 Conference Dublin City University. Dublin, Ireland. 
Walsh, J., \& Vandiver, D. (2007). Fostering student centered learning (SCL) through the use of active learning exercises in undergraduate research methods courses. Retrieved from https://sotl.illinoisstate.edu/scholarship/snapshots/walsh.html.

Wolk, R. (2010). Education: The case for making it personal. Edu Lead, 67(7), 16-21.

Zohrabi, M., Torabi, M. A., \& Baybourdiani, P. (2012). Teacher-centered and/or student-centered learning: English language in Iran. English Lang and Literature Studies, 2(3), 18-30. 